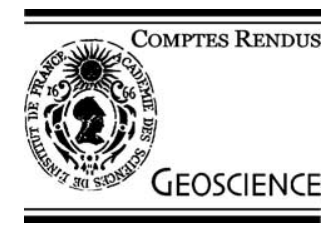

Geodynamics / Géodynamique

\title{
A 'core-complex-like structure' formed by superimposed extension, folding and high-angle normal faulting. The Santi Petri dome (western Betics, Spain)
}

\section{Une structure «pseudo-core-complex» formée par la superposition d'extension, plissement et fracturation normale à fort pendage : le dôme de Santi Petri (Cordillères bétiques occidentales, Espagne)}

\author{
Guillermo Booth-Rea ${ }^{\mathrm{a}, *}$, José Miguel Azañón ${ }^{\mathrm{a}}$, Víctor García-Dueñas a , \\ Romain Augier ${ }^{\mathrm{b}}$, Mario Sánchez-Gómez ${ }^{\mathrm{c}}$ \\ a Departamento de Geodinámica, Universidad de Granada, 18071 Granada, Spain \\ ${ }^{\mathrm{b}}$ Laboratoire de tectonique, UMR 7072, université Pierre-et-Marie-Curie, tour 26-25 E1, case 129, 4, place Jussieu, \\ 75252 Paris cedex 05, France \\ c Departamento de Geología, Universidad de Jaén, 23071 Jaén, Spain
}

Received 10 September 2002; accepted 4 February 2003

Presented by Michel Durand-Delga

\begin{abstract}
The Santi Petri dome (western Betics, southern Spain) shows a core-complex-like structure, where migmatitic gneisses and schists outcrop below low-grade slates and phyllites, all of which form the basement of the Neogene Málaga basin. The migmatites and schists suffered a coaxial-flattening event during isothermal decompression and were later exhumed by ductile ESE non-coaxial stretching. Further exhumation was achieved by W- to SW-transport brittle low-angle normal faulting. Subsequently these extensional structures were gently folded in the core of a NE/SW-oriented antiform during the Tortonian. Finally the Santi Petri domal geometry was accentuated by the interference of orthogonal high-angle faults with ENE-WSW and NNW-SSE orientation. This core-complex-like structure, formed by superposition of extensional and compressive tectonic events, does not represent a classical, purely extensional core complex, which shows that metamorphic structure and geometry are not decisive criteria to define a core-complex.

@ 2003 Académie des sciences/Éditions scientifiques et médicales Elsevier SAS. All rights reserved.
\end{abstract}

\section{Résumé}

Le dôme de Santi Petri (Cordillères bétiques occidentales, Espagne) montre une structure de type core-complex, où affleurent des gneiss migmatitiques et des schistes directement sous des phyllites peu métamorphiques, toutes ces roches formant le substratum du bassin de Málaga. Les schistes et les migmatites ont tout d'abord, durant leur décompression isotherme, subi

\footnotetext{
* Corresponding author.

E-mail address: gbooth@geomar.de (G. Booth-Rea).
} 
un aplatissement coaxial (symétrique) évoluant plus tardivement en un étirement ductile ESE «non coaxial». L'exhumation de ces roches initiée dans des conditions ductiles s'est prolongée dans des conditions cassantes, avec un épisode de fracturation en failles normales de faible pendage à transport vers l'ouest et le sud-ouest. Ces structures extensives ont ensuite été plissées selon un axe antiforme NE-SW durant le Tortonien. La géométrie en dôme résultante fut finalement accentuée par l'interférence de deux systèmes orthogonaux de failles normales à fort pendage avec des orientations ENE-WSW et NNW-SSE. Ainsi, le dôme de Santi Petri, avec une géométrie analogue à celle d'un core-complex, est né de la superposition d'épisodes tectoniques extensifs et compressifs, contrairement aux core-complexes typiques. Les critères géométriques et architecturaux ne suffisent donc pas pour caractériser un core-complex.

(C) 2003 Académie des sciences/Éditions scientifiques et médicales Elsevier SAS. Tous droits réservés.

Keywords: Core-complex; Alboran domain; Western Betics; Malaga; Spain

Mots-clés : Core-complex; Domaine d'Alboran ; Bétiques occidentales ; Malaga ; Espagne

\section{Version française abrégée}

\section{Introduction}

L'exhumation des gneiss de haut degré et des granulites dans les metamorphic core-complexes (MCC) est communément attribuée à l'activité de plusieurs générations de détachements extensifs, qui exhument progressivement ces roches en les amenant au niveau de roches peu ou pas métamorphiques [23,31]. Ce processus agit en concomitance avec le fluage de la croûte inférieure et moyenne située directement sous le corecomplex $[4,12,46,51]$.

Il existe, dans les Cordillères bétiques, plusieurs exemples de fenêtres tectoniques où un socle métamorphique affleure directement sous des roches équilibrées dans des conditions métamorphiques bien moindres. C'est le cas, par exemple, dans la chaîne montagneuse de la Sierra Nevada (Bétiques centrales) $[29,35,36]$ ou celle de la Sierra de las Estancias, Sierra de la Tercia et Sierra Espuña (Nord-Est des Bétiques) [1,13,32].

Nous présentons dans cette étude la structure et l'évolution tectonique d'une structure de type corecomplex située dans les Cordillères bétiques occidentales (Sierra de Santi Petri, province de Malaga, Fig. 1).

\section{Contexte géologique}

L'arc de Gibraltar constitue la terminaison occidentale de la chaîne alpine péri-méditerranéenne. Il s'est formé durant la période Oligocène terminal-Miocène inférieur par l'accrétion de plusieurs domaines crustaux, charriés [9,14,22] sur la zone sud-ibérique, au nord, et sur la zone externe maghrébine, au sud. Ces terrains allochtones forment la partie interne de l'arc appelé «domaine d'Alboran » [9] ou «terrain d'Alboran » $[18,39]$; qui repose structuralement sur les unités des Flyschs [9].

Le domaine d'Alboran est composé par l'empilement de trois principaux complexes, avec, de bas en haut : le complexe Névado-Filabride, le complexe Alpujarride/Sebtide [24] et Malaguide/Ghomaride [17], l'élément tectonique supérieur étant représenté par les unités de la Dorsale [8,9]. Les deux complexes structuralement les plus profonds ont respectivement subi, durant l'orogenèse alpine, des conditions métamorphiques allant jusqu'au faciès éclogite. Le complexe Malaguide/Ghomaride n'a, quant à lui, atteint que des conditions métamorphiques à schiste vert de faible degré, pour ses parties les plus profondes [17,32,42].

De façon contemporaine du mouvement vers l'ouest de l'arc de Gibraltar, la partie centrale du domaine crustal d'Alboran était soumise à une extension arrièrearc. Dans la situation actuelle, les principales unités tectoniques du domaine sont séparées par des contacts extensifs : des zones de cisaillements ductiles ainsi que des accidents cassants [1,13,18,21,29,30,32,34, 36]. Ces unités, actuellement émergées et affleurant dans les Bétiques, forment aussi le socle du bassin d'Alboran et des bassins marins néogènes, comme celui de Malaga [20] (Fig. 1).

\section{Structure du dôme de Santi Petri}

La foliation principale rencontrée dans les roches alpujarrides au cœur du dôme de Santi Petri est un clivage de crénulation (Scc), plan axial de pli couché. Cette foliation oblitère complètement la fabrique planaire initiale dans la majorité des terrains alpujar- 
rides, excepté dans leurs termes les plus hauts, où une fabrique métamorphique (Ss) est préservée dans de rares domaines lenticulaires. La foliation Scc se développe durant l'épisode de décompression isotherme de la roche après la culmination métamorphique enregistrée par les assemblages minéraux [2,6,7,10,11]. De fait, cette foliation a été interprétée par de nombreux auteurs comme une fabrique extensive, formée durant un épisode d'aplatissement symétrique (cisaillement pur), avec un facteur d'atténuation d'environ 3 [2,6, $7,10,11]$.

Comme la plus grande partie de la série Alpujarride, la foliation Scc a été affectée, plus tardivement, par un étirement non coaxial développant des textures proto-mylonitiques ou blasto-mylonitiques, associées à une linéation d'étirement [10,11]. Cette linéation, d'orientation principalement ENE à ESE (dans le dôme de Santi Pétri) est définie par l'orientation préférentielle des phyllosilicates, des agrégats de fibres de sillimanite [3] et des andalousites, qui sont tant syn- que post-cinématiques par rapport à l'étirement. Localement, dans la partie la plus profonde de la structure, la linéation est méridienne (vecteurs cinématiques ductiles, Fig. 2).

La foliation Scc est fréquemment affectée par des zones de cisaillement ductile de faible pendage, indiquant une extension ESE. Les porphyroblastes syncinématiques montrent des rotations cohérentes avec ce cisaillement (Fig. 3a). Cette extension, qui se prolonge dans des conditions cassantes, est accommodée par des accidents d'échelle décamétrique, donnant une même extension ESE.

Ces structures extensives sont recoupées par un système cassant avec extension WSW-ENE, qui forme les contacts actuels entre les formations alpujarrides et les formations malaguides (vecteurs de déplacement cassant, Fig. 2 et Fig. 3b). Ce système extensif cassant est formé par des failles à faible pendage, avec une géométrie en replats et rampes qui s'enracinent sur un détachement principal et qui affectent les gneiss migmatitiques alpujarrides. Le déplacement sur ces failles normales à faible pendage a entraîné le ploiement des roches du toit lors de leur passage aux charnières entre plat et rampe (Fig. 3). Il y a donc en développement de plis NW-SE orthogonaux à la direction de transport (Fig. 3).

Le principal accident à faible pendage dont le mouvement est vers le sud-ouest présente un pendage ac- tuel nord-ouest sur le flanc nord-ouest du dôme de Santi Petri et vers le sud-est sur son flanc sud-est. Cette orientation est le résultat du plissement néogène dans la région de Malaga. Cette phase de serrage, connue aussi dans d'autres zones des Cordillères bétiques, est attribuée au Tortonien, comme l'attestent les discordances intratortoniennes régionales [10,22,28].

La géométrie du dôme de Santi Petri a finalement été encore accentuée par l'activité de deux systèmes de failles normales à fort pendage, avec des orientations NNW-SSE et ENE-WSW, qui ont produit une structure de type «horst bi-directionnel » (Figs. 2 et 3 ).

\section{Discussion}

Dans le dôme de Santi Petri, le système extensif cassant n'est pas en relation avec l'amincissement ductile non coaxial, contrairement aux core-complexes «classiques» [31,51], dans lesquels le cisaillement ductile dans la croûte inférieure est en relation avec l'amincissement cassant caractérisant la croûte supérieure. En outre, le cisaillement ductile et le jeu cassant sur les failles normales à faible pendage montrent des cinématiques très différentes.

La géométrie actuelle du dôme de Santi Petri a été initiée durant le Tortonien par un raccourcissement de direction nord-ouest, qui a affecté le socle et les sédiments discordants du Miocène inférieur de la région de Malaga, avec un plissement d'axe SW-NE.

Cette géométrie a été accentuée par un épisode tardif de fracturation. Deux systèmes de failles normales à fort pendage, d'orientations respectivement ENEWSW et NNW-SSE, recoupent les failles normales à faible pendage caractérisant le premier épisode extensif et constituent les bordures actuelles du Sud et de l'Ouest du dôme de Santi Petri.

Le dôme métamorphique de Santi Petri est un exemple qui montre qu'une géométrie en core-complex peut être la conséquence de la superposition de plusieurs épisodes tectoniques, dans d'autres contextes que ceux qui ont initialement été proposés par Lister et Davis [31] ou Wernicke [51]. La géométrie et la structure métamorphique ne fournissent pas d'argument suffisant pour définir un core-complex, en particulier dans les zones caractérisées par une cinématique complexe, comme c'est le cas dans les orogènes de l'Ouest de la Méditerranée. 


\section{Introduction}

The exhumation of high-grade gneisses and granulites in metamorphic core-complexes (MCC) has been commonly attributed to the sequential activity of multiple generations of detachments, which progressively exhume the high-grade metamorphic rocks below non-metamorphic or low-grade rocks [23,31]. The low-angle extensional faulting occurs together with differential pressure-driven, lateral flow of the lower or middle crust into the area beneath the MCC $[4,12$, 46,51].

In the Betic chains, there are several examples of extensional windows where the metamorphic basement outcrops below lower-grade rocks or below the sedimentary basins cover, for example the Sierra Nevada mountain range $[29,35,36]$ or in the northeastern Betics [1,13,32]. These extensional tectonic windows presently outcrop as elongated domes that coincide with anticlinal ridges. In the case of the Sierra Nevada elongated dome, Middle to Upper Miocene extension migrated towards the southwest coeval to north-south shortening and uplifting of the footwall favoured by midcrustal ductile flow [35,36].

On the other hand, some extensional windows that outcrop in the Betics show a smaller size, not being sufficiently large to produce perturbations in the lower crust. In these smaller domes, the ductile thinning is unrelated to the later brittle extensional systems; extension generally predated the Upper Neogene shortening event [13]. As an example of these smaller extensional windows, we present the structure and tectonic evolution of an extensional dome that outcrops in the western Betics (Sierra de Santi Petri, Málaga Province, Fig. 1).

\section{Geological setting}

The Gibraltar Arc constitutes the western end of the Perimediterranean Alpine Orogen. It was accreted during the Upper Oligocene to Lower Miocene [9, $14,22]$ by the westward oblique superposition of several pre-Miocene crustal domains that were thrusted over the South-Iberian and Maghrebian external domains, which constituted respectively the southern and northern Mesozoic palaeomargins of the Iberian and African plates. The allochthonous terrains found in the

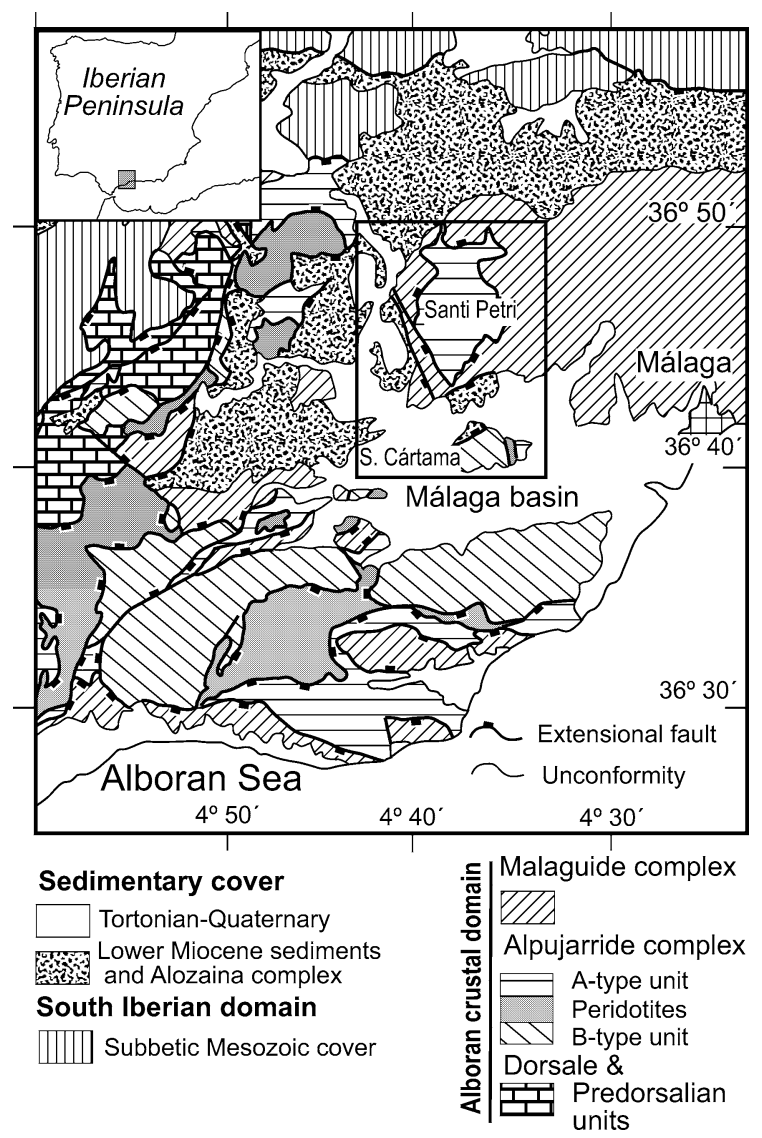

Fig. 1. Geological setting of the Santi Petri dome.

Fig. 1. Situation géologique du dôme de Santi Petri.

internal part of the arc constitute the Alboran crustal domain (ACD) [18,39]. Below the ACD lie the Flyschs Trough units, formed by a detached MesozoicTertiary sedimentary cover of a deep trough, floored by oceanic or thinned continental crust [25,27].

The Alboran domain is a terrain formed from bottom to top by the Nevado-Filabride, Alpujarride/Sebtide [24] and the Malaguide/Ghomaride [17] complexes, together with the Dorsale and Predorsalian units [8,9]. The two lowest complexes underwent plurifacial metamorphism during the Alpine orogeny $[6,7,10]$ and also during the Hercynian in the Alpujarride Palaeozoic rocks [52]. Meanwhile, the Malaguide complex only underwent Alpine anchizone metamorphism in its lowest thrust sheets [32,42], although the Malaguide Palaeozoic pre-Carboniferous 
rocks show lower greenschist-facies metamorphism that has been attributed to the Hercynian Orogeny [17].

Contemporary to the westward migration of the Arc, the Alboran crustal domain was greatly extended in the back-arc, so the present-day main tectonic units of this domain are extensional units, bounded by brittle and ductile shear zones [1,13,18,21,29,30,32,34,36] that constitute the basement of the Alboran basin and of other Neogene marine basins, presently emerged and outcropping in the Betics [20] (e.g., the Málaga Basin, Fig. 1).

The extensional structures generated during the rifting of the Alboran domain greatly attenuate the basement of the Málaga basin that outcrops in the Santi Petri dome. The core of this dome shows K-feldspar migmatitic gneisses and graphite schists of the highest Alpujarride unit (A-type unit, as defined by Azañón et al., [5]) outcropping below Palaeozoic phyllites and slates of the Malaguide complex [19,40, 41] (Fig. 2).

Tectonic subsidence of the Málaga basin related with the extensional structures that outcrop in the Santi Petri dome permitted the deposition of a thick sequence of Lower-Miocene-to-Pliocene marine sediments. The oldest sediments have been grouped in three formations: (1) the Alozaina Formation (conglomerates, sandstones and marls) of Uppermost Oligocene [26] or Lower-Aquitanian age [15]; (2) the Millanas Formation constituted by approximately $50 \mathrm{~m}$ of marine shales and marls of Aquitanian to LowerBurdigalian age $[15,26]$ that outcrop in the southern border of the Santi Petri dome (Fig. 2); (3) the Neonumidian $[8,9,15]$, formed by a thick sequence of Burdigalian brown clays, which include frequent exotic olistholiths and clasts of Mesozoic and Tertiary sediments. These olistholiths proceeded from backthrusted units (Dorsale and Predorsalian units) of the Gibraltar accretionary prism [8].

An erosive unconformity separates the LowerMiocene sediments from Upper-Tortonian shallow marine conglomerates and calcirudites. Following a Messinian emersion, the marine sedimentation started again in the Pliocene, then the Málaga basin definitely emerged [33].

\section{Structure of the Santi Petri dome}

The main foliation found in the Alpujarride rocks outcropping in the core of the Santi Petri dome is a penetrative crenulation cleavage (Scc) axial plane of similar folds. This foliation completely obliterates previous planar fabrics in most of the Alpujarride section, except in its highest terms, where a previous differentiated metamorphic fabric (Ss) is preserved in the Scc lenticular domains. The Scc is gently dipping, except in the Southwestern border of the Santi Petri dome where it dips $40-60^{\circ}$ towards the WSW, and is mainly subparallel to the lithologic banding and to the metamorphic zonation as in other areas of the Betics $[2,6,7,10,11]$. The Scc foliation developed coeval to an isothermal decompression event registered in the metamorphic mineral assemblages $[2,6,7,10,11]$. Thus, this foliation has been interpreted as an extensional fabric, which formed during a coaxial flattening event with an attenuation factor of approximately 3 [2, $6,7,10,11]$.

In most of the Alpujarride section the Scc foliation was later affected by a non-coaxial stretching that developed protomylonitic or blastomylonitic textures with an associated stretching lineation [10,11]. This lineation with a mostly ENE-to-ESE orientation (in the Santi Petri dome) is defined by the preferential orientation of phyllosilicates, sillimanite bundles [3] and andalusite, which is both syn- and post-kinematic to the stretching. Locally in the deepest parts of the Santi Petri dome, the stretching lineation shows a north-south orientation (see ductile kinematic vectors, Fig. 2). This shearing shows eastward to northward transport sense in other areas of the western Betics (under present geographical coordinates) $[2,10,11,48]$.

In the Santi Petri area, porphyroblast structures synkinematic to the stretching event show mostly eastward shearing (see ductile kinematic vectors in Fig. 2, and porphyroblast in Fig. 3a). The Scc foliation is frequently cut by an extensional cleavage, in the sense of Platt [44], and by low-angle ductile shear bands that indicate mostly ESE shearing. Further extension was accommodated by brittle distributed small-scale shearing with the same ESE tectonic transport.

Post-Scc large-scale asymmetric folds and associated crenulation, and cleavage commonly described in Alpujarride units of the central and eastern Betics 


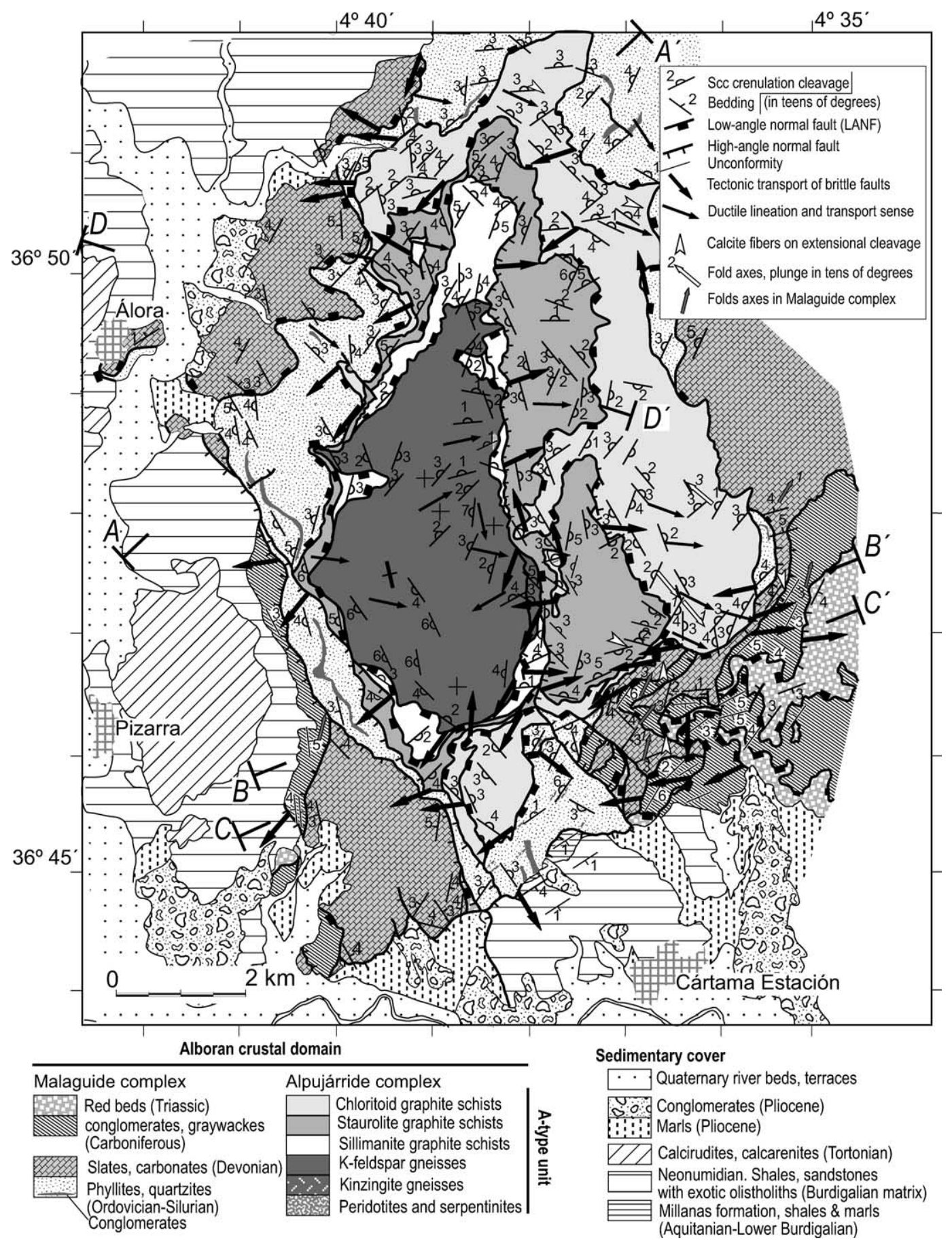

Fig. 2. Structural map of the Santi Petri dome. Cross-sections are represented in Fig. 3.

Fig. 2. Carte structurale du dôme de Santi Petri. Les coupes géologiques sont représentées sur la Fig. 3. 


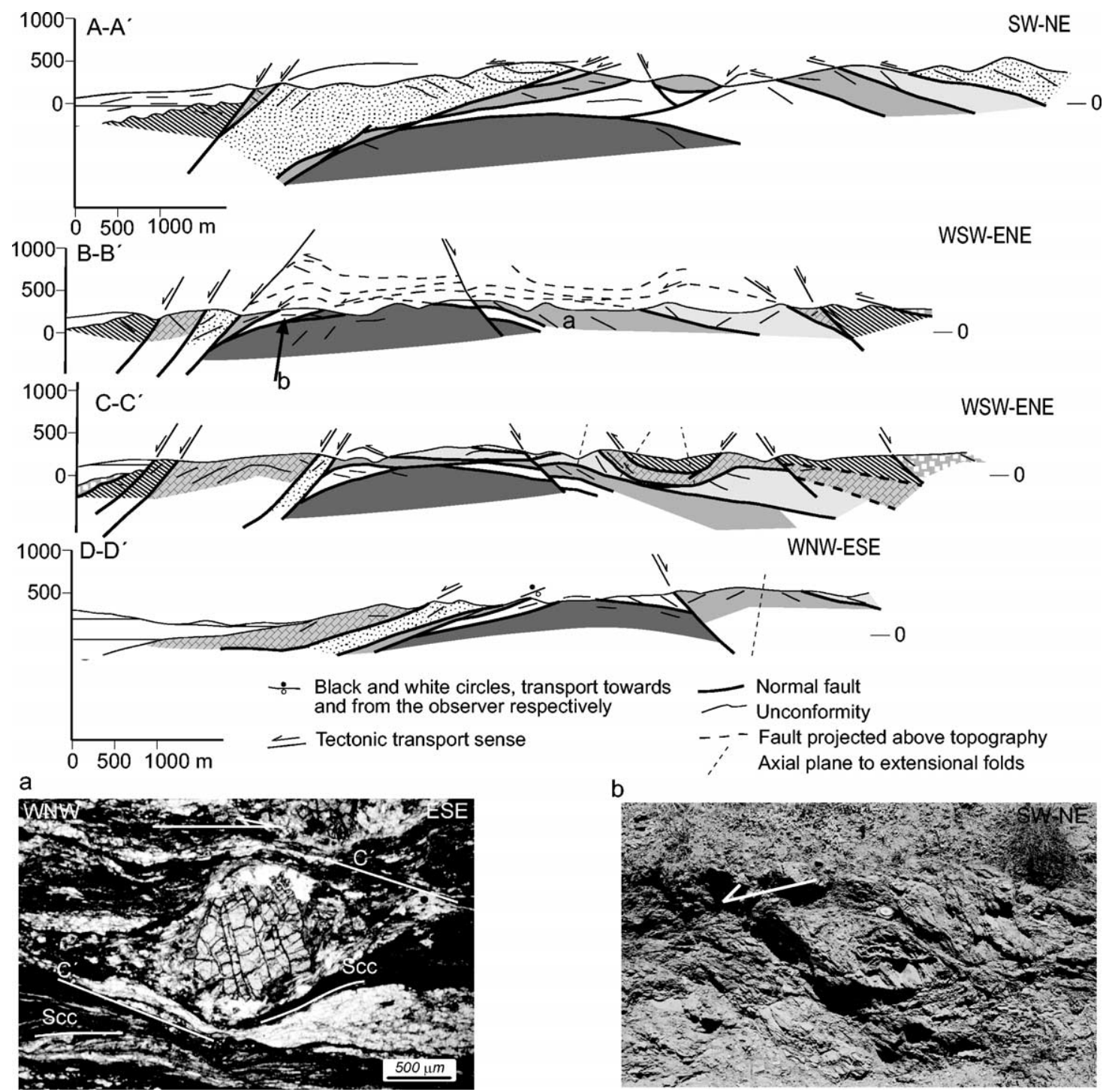

Fig. 3. Geological cross-sections of the Santi Petri dome. Sections localisation and lithostratigraphic legend are represented in Fig. 2. (A) Sheared garnet indicating post-Scc ESE ductile transport. (B) Rotated brittle porphyroclast showing SW tectonic transport.

Fig. 3. Coupes géologiques du dôme de Santi Petri. La localisation des coupes et la légende lithostratigraphique sont données sur la Fig. 2. (A) Grenat cisaillé, indiquant un transport ENE, post Scc, sous des conditions ductiles. (B) Porphyroclaste montrant un transport tectonique vers le sud-ouest cassant.

$[5,6,43]$ are rare in the Santi Petri dome where only a few folds have been identified, which have NWSE-oriented axes (Fig. 2). This is probably due to the fact that the studied rocks together with the Malaguide complex formed part of the hanging wall of the Alboran domain during the late-to-post-metamorphic thrusting event that determined the structure of this do- main, where high-grade metamorphic units are found lying above lower-grade ones $[6,7,11]$. Thus, the hanging wall of the Alboran domain was mostly undeformed during this late thrusting event.

The ductile ESE-transport extensional structures are affected by a brittle WSW-ENE-transport extensional system, which has configured the present con- 
tacts among the Alpujarride and Malaguide formations (see structural map and brittle kinematic vectors, Fig. 2 and kynematic indicator, Fig. 3b). This extensional system is formed by low-angle normal faults with a ramp-flat geometry, which detach above an extensional detachment that cuts down into the Alpujarride migmatitic gneisses. Displacement along the ramp-flat geometry of the low-angle normal faults has folded the hanging-wall rocks, which show gentle folds with NW-SE-oriented axes, transverse to the extensional transport (see cross-sections in Fig. 3). For example, in the southeastern border of the Santi Petri dome, there is a low-angle normal fault with southwestward transport, which has a hanging-wall flat formed by Malaguide rocks resting on a footwall ramp that cuts the chloritoid-bearing Alpujarride graphite schists. This geometry produces a hangingwall syncline above the footwall ramp (cross section B-B', Fig. 3).

The north-south-oriented antiform that contributes to the north-south elongation of the Santi Petri dome (Fig. 2) probably formed as one of these fault-bend folds, related with the ramp-flat geometry of an eastward-transport normal fault found below the Santi Petri dome. The southwest dipping gneisses in the core of the Santi Petri dome would represent a hangingwall ramp above an underlying footwall flat.

The Malaguide rocks are frequently intruded upon by Oligocene or Lower-Miocene tholeiite dike swarms $[47,50]$ that show a SW-NE orientation in the area. These dikes are tilted by low-angle NW/SE-transport normal faults that do not fault the Alpujarride rocks. Other extensional structures in the Malaguide complex, like extensional cleavage and calcite veins, also indicate both northern and southern tectonic transport under present geographical coordinates. Palaeomagnetic data indicate that the tholeiitic dikes have suffered vertical-axis clockwise rotations of 90 to $140^{\circ}$ after being tilted $[16,45]$ so the original extensional transport direction related with both the dikes and the NW/SE-transport low-angle faults must have had an east-west component.

The main SW-transport low-angle normal faults presently appear folded, dipping towards the northwest in the northwestern border of the Santi Petri dome and towards the southeast in the southeastern border. This orientation is the result of Neogene folding of the Malaga area (see folds traces in Fig. 1). In the south- eastern limb of the Santi Petri dome, the Burdigalian marine marls locally dip up to $40^{\circ}$ although they generally dip gently towards the SSE. An ENE-elongated dome outcrops to the south of the Santi Petri dome (the Sierra de Cartama, Fig. 1) that shows an antiformal structure [49] that folds the Burdigalian sedimentary sequence and is sealed by Upper-Tortonian marine conglomerates. This folding event most probably took place during the Tortonian as in other areas of the Betics, where intra-Tortonian erosive unconformities have been found $[13,22,28]$.

The Santi Petri dome shape was accentuated by the activity of two sets of high-angle faults with NNW-SSE and ENE-WSW orientation that produced a bi-directional horst structure (see structural map, Fig. 2). These faults configured the present boundaries between the Malaga-basin sedimentary cover and the metamorphic basement. The listric geometry of a few of these faults generated gentle rollovers in the hanging-wall rocks (see cross-section $\mathrm{C}-\mathrm{C}^{\prime}$, Fig. 3). Locally these high-angle faults cut the Pliocene marine sediments, evidencing their recent activity and their influence on the present topographical highs where the basement of the Malaga basin outcrops.

\section{Discussion}

The Santi Petri metamorphic dome shows a corecomplex-like geometry where, contrary to a typical core-complex [31], there is no relationship between the brittle extensional faults and the plastic thinning. This core-complex-like geometry was reached by the superposition of successive, near orthogonal, extensional systems and folding.

The early structure was produced by plastic ESE extensional shearing of the Alpujarride units before they were emplaced in the Gibraltar accretionary prism. Meanwhile the southwest-directed low-angle extensional faults were superimposed on the Alpujarride ductile fabrics and achieved the inversion of the Gibraltar Arc tectonic front.

After the main extension, the final dome geometry of the Santi Petri metamorphic core was initiated by Tortonian northwest-directed shortening that gently folded the basement and the Lower-Miocene sediments, although it was further accentuated by Tortonian-to-Pliocene high-angle faulting. Two sets of high-angle normal faults with ENE-WSW and NNW- 
SSE tectonic transport faulted the previous southwesttransport low-angle normal faults and configured the southern, eastern and western boundaries of the Santi Petri dome.

The Santi Petri metamorphic dome together with other core-complex-like structures described in the literature $[37,38]$ are examples that core-complex geometries can be obtained by superposition of tectonic events, in a different way than initially proposed by Lister and Davis [31] or Wernicke [51]. Thus, the geometry is not a definitive reason to define a corecomplex, particularly in areas with complex kinematic histories, as occurs in the western Mediterranean orogens.

\section{Acknowledgements}

The MCYT Spanish projects REN2001-3868-CO301/MAR and REN2001-3378, and FEDER founds of the UE supported the field and laboratory research. We are grateful to A. Michard and to an anonymous referee for their constructive reviews.

\section{References}

[1] F. Aldaya, F. Alvarez, J. Galindo-Zaldívar, F. GonzálezLodeiro, A. Jabaloy, F. Navarro-Vilá, The MalaguideAlpujarride contact (Betic Cordilleras, Spain): a brittle extensional detachment, C. R. Acad. Sci. Paris, Ser. II 313 (1991) 1447-1453.

[2] T.W. Argles, J.P. Platt, D.J. Waters, Attenuation and Excision of a Crustal Section During Extensional Exhumation - The Carratraca Massif, Betic Cordillera, Southern Spain, J. Geol. Soc. 156 (1999) 149-162.

[3] T.W. Argles, J.P. Platt, Stepped fibers in sillimanite-bearing veins - Valid shear-sense indicators in high-grade rocks, J. Struct. Geol. 21 (1999) 153-159.

[4] G. Axen, J. Bartley, J. Selverstone, Structural expression of a rolling hinge in the footwall of the Brenner Line normal fault, eastern Alps, Tectonics 14 (1995) 1380-1392.

[5] J.M. Azañón, V. García-Dueñas, J.M. Martínez-Martínez, A. Crespo-Blanc, Alpujarride tectonic sheets in the central Betics and similar eastern allochthonous units (SE Spain), C. R. Acad. Sci. Paris, Ser. II 318 (1994) 667-674.

[6] J.M. Azañón, A. Crespo Blanc, V. García Dueñas, Continental collision, crustal thinning and nappe-forming during the PreMiocene evolution of the Alpujárride Complex (Alborán Domain, Betics), J. Struct. Geol. 19 (1997) 1055-1071.

[7] J.M. Azañón, A. Crespo Blanc, Exhumation during a continental collision inferred from the tectonometamorphic evolution of the Alpujarride Complex in the central Betics (Alboran Domain, SE Spain), Tectonics 19 (2000) 549-565.
[8] J.C. Balanyá, V. García-Dueñas, Grandes fallas de contracción y extensión implicadas en el contacto entre los dominios de Alborán y Sudibérico en el Arco de Gibraltar, Geogaceta 1 (1986) 19-21.

[9] J.C. Balanyá, V. García-Dueñas, Les directions structurales dans le domaine d'Alborán de part et d'autre du détroit de Gibraltar, C. R. Acad. Sci. Paris, Ser. II 304 (1987) 929-932.

[10] J.C. Balanyá, J.M. Azañón, M. Sánchez-Gómez, V. GarcíaDueñas, Pervasive ductile extension, isothermal decompression and thinning of the Jubrique unit in the Paleogene (Alpujárride Complex, western Betics Spain), C. R. Acad. Sci. Paris, Ser. II 316 (1993) 1595-1601.

[11] J.C. Balanyá, V. García-Dueñas, J.M. Azañón, M. SánchezGómez, Alternating contractional and extensional events in the Alpujarride nappes of the Alboran Domain (Betics, Gibraltar Arc), Tectonics 16 (1997) 226-238.

[12] L. Block, L. Royden, Core-complex geometries and regional scale flow in the lower crust, Tectonics 9 (1990) 557-567.

[13] G. Booth-Rea, V. García-Dueñas, J.M. Azañón, Extensional attenuation of the Malaguide and Alpujarride thrust sheets in a segment of the Alboran Basin folded during the Tortonian (Lorca area, Eastern Betics), C. R. Geoscience 334 (2002) 557-563.

[14] J.-P. Bouillin, M. Durand-Delga, P. Olivier, Betic-Rifian and Tyrhenian Arcs: distinctive features, genesis, and development stages, in: F.C. Wezel (Ed.), The origin of Arcs, Vol. 21, Elsevier Science Publishers, Amsterdam, 1986, pp. 281-304.

[15] J. Bourgois, P. Chauve, J. Magné, J. Monnot, Y. Peyre, E. Rigo, M. Rivière, La Formation de Las Millanas. Série burdigalienne transgressive sur les zones internes des Cordillères bétiques occidentales (région d'Alozaina-Tolox, province de Malaga, Espagne), C. R. Acad. Sci. Paris, Ser. D 275 (1972) 169-172.

[16] M. Calvo, J. Cuevas, J. Tubía, Preliminary paleomagnetic results on Oligocene-Early-Miocene mafic dykes from southern Spain, Tectonophysics 332 (2001) 333-345.

[17] A. Chalouan, A. Michard, The Ghomarides nappes, Rif coastal range, Morocco: a variscan chip in the Alpine belt, Tectonics 9 (1990) 1565-1583.

[18] A. Chalouan, A. Michard, H. Feinberg, R. Montigny, C. Saddiqui, The Rif mountain building (Morocco): a new tectonic scenario, Bull. Soc. géol. France 172 (2001) 603-616.

[19] C. Chamón-Cobos, R. Quinquer-Agut, V. Crespo, M. Aguilar, J.L. Reyes, Mapa Geológico y Minero de España 1052 (Alora), IGME, Madrid, 1976.

[20] M.C. Comas, J.P. Platt, J.I. Soto, A.B. Watts, The origin and tectonic history of the Alborán Basin: insights from Leg 161 results, in: R. Zahn, M.C. Comas, A. Klaus, Proc. ODP Sci. Results 161 (1999) 555-579.

[21] A. Crespo-Blanc, Interference pattern of extensional fault systems: a case study of the Miocene rifting of the Alboran basement (North of Sierra Nevada, Betic Chain), J. Struct. Geol. 17 (1995) 1559-1569.

[22] A. Crespo-Blanc, J. Campos, Structure and kinematics of the South Iberian paleomargin and its relationship with the Flysch Trough units: extensional tectonics within the Gibraltar Arc fold-and-thrust belt (western Betics), J. Struct. Geol. 23 (2001) 1615-1630. 
[23] M. Crittenden, P. Coney, G. Davis (Eds.), Tectonic significance of metamorphic core complexes of the North American Cordillera, Mem. Geol. Soc. Am. 153 (1980).

[24] J. Didon, M. Durand-Delga, J. Kornprobst, Homologies géologiques entre les deux rives du détroit de Gibraltar, Bull. Soc. géol. France 7 (15) (1973) 77-105.

[25] M. Durand-Delga, La Méditerranée occidentale : étapes de sa genèse et problèmes structuraux liés à celle-ci, Mém. h.-sér. Soc. géol. France 10 (1980) 203-224.

[26] M. Durand-Delga, H. Feinberg, J. Magné, P. Olivier, R. Anglada, Les formations oligo-miocènes discordantes sur les Malaguides et les Alpujarrides et leurs implications dans l'évolution géodynamique des Cordillères bétiques (Espagne) et la Méditerranée d'Alboran, C. R. Acad. Sci. Paris, Ser. II 317 (1993) 679-687.

[27] M. Durand-Delga, P. Rossi, P. Olivier, D. Puglisi, Situation structurale et nature ophiolitique des roches basiques jurassiques associées aux flyschs maghrébins du Rif (Maroc) et de Sicile (Italie), C. R. Acad. Sci. Paris, Ser. IIa 331 (2000) 29-38.

[28] A. Estévez, J. Rodríguez-Fernández, C. Sanz de Galdeano, J.A. Vera, Evidencia de una fase compresiva de edad Tortonense en el sector central de las Cordilleras Béticas, Estud. Geol. 38 (1982) 55-60.

[29] J. Galindo-Zaldívar, F. González-Lodeiro, A. Jabaloy, Progressive extensional shear structures in a detachment contact in the Western Sierra Nevada (Betic Cordilleras, Spain), Geodin. Acta 3 (1989) 73-85.

[30] V. García-Dueñas, J.C. Balanyá, J.M. Martínez-Martínez, Miocene extensional detachments in the outcropping basement of the northern Alboran Basin (Betics) and their tectonic implications, GeoMar. Lett. 12 (1992) 88-95.

[31] S.G. Lister, A.G. Davis, The origin of metamorphic core complexes and detachment faults formed during Tertiary continental extension in the northern Colorado River region, USA, J. Struct. Geol. 11 (1989) 65-94.

[32] L. Lonergan, J. Platt, The Malaguide-Alpujarride boundary: a major extensional contact in the Internal Zone of the eastern Betic Cordillera, SE Spain, J. Struct. Geol. 17 (1995) 16651671.

[33] A.C. López-Garrido, C. Sanz de Galdeano, Neogene Sedimentation and Tectonic-Eustatic Control of the Malaga Basin, South Spain, J. Petrol. Geol. 22 (1999) 81-96.

[34] J.M. Martínez-Martínez, J.M. Azañón, Mode of extensional tectonics in the southeastern Betics (SE Spain). Implications for the tectonic evolution of the peri-Alborán orogenic system, Tectonics 16 (1997) 205-225.

[35] J.M. Martínez-Martínez, J.I. Soto, J.C. Balanyá, Crustal decoupling and intracrustal flow beneath domal exhumed core complexes, Betic (SE Spain), Terra Nova (1997).

[36] J.M. Martínez-Martínez, J.I. Soto, J.C. Balanyá, Orthogonal folding of extensional detachments: structure and origin of the Sierra Nevada elongated dome (Betics, SE Spain), Tectonics (in press).

[37] P. Matte, J. Lancelot, M. Mattauer, La zone axiale hercynienne de la Montagne noire n'est pas un metamorphic core-complex extensif, mais un anticlinal post-nappe à cœur anatectique,
Geodin. Acta 1998 (1998) 13-22.

[38] A. Michard, B. Goffe, C. Chopin, C. Henry, Did the western Alps develop through an Oman-type stage - The geotectonic setting of high-pressure metamorphism in two contrasting Tethyan transects, Eclog. Geol. Helv. 89 (1996) 43-80.

[39] A. Michard, A. Chalouan, H. Feinberg, B. Goffé, R. Montigny, How does the Alpine belt end between Spain and Morocco?, Bull. Soc. géol. France 173 (2002) 3-15.

[40] R.M. Mon, Rapports entre la nappe de Malaga et les unités alpujarrides à l'Ouest de Malaga (Espagne), C. R. Acad. Sci. Paris, Ser. D 268 (1969) 1008-1011.

[41] R. Mon, Estudio geológico del extremo occidental de los Montes de Málaga, y de la Sierra de Cártama (Prov. de Málaga), Bol. Geol. Min. 62 (1971) 132-146.

[42] F. Nieto, N. Velilla, D.R. Peacor, M. Ortega-Huertas, Regional retrograde alteration of sub-greenschist facies chlorite to smectite, Contrib. Mineral. Petrol. 115 (1994) 243-252.

[43] M. Orozco, F.M. Alonso-Chaves, F. Nieto, Development of large north-facing folds and its relation with crustal extension in the Alborán domain (Alpujarras region, Betic Cordilleras), Tectonophysics 56 (1998) 277-295.

[44] J.P. Platt, R.L.M. Vissers, Extensional structures in anisotropic rocks, J. Struct. Geol. 2 (1980) 379-410.

[45] E. Platzman, J. Platt, S. Kelley, S. Allerton, Large clockwise rotations in an extensional allochthon, Alboran Domain (southern Spain), J. Geol. Soc. Lond. 157 (2000) 1187-1197.

[46] J. Spencer, S. Reynolds, Tectonics of mid-Tertiary extension along a transect through west central Arizona, Tectonics 10 (1991) 1204-1221.

[47] R.L. Torres-Roldán, G. Poli, A. Peccerillo, An Early Miocene arc-tholeiitic magmatic dike event from the Alboran Sea - Evidence for precollisional subduction and back-arc crustal extension in the westernmost Mediterranean, Geol. Rundsch. 75 (1986) 219-234.

[48] J. Tubía, F. Navarro-Vila, J. Cuevas, The Maláguide-Los Reales Nappe: an example of crustal thinning related to the emplacement of the Ronda peridotites (Betic Cordillera), Phys. Earth Planet. Inter. 78 (1993) 343-354.

[49] J.M. Tubía, J. Cuevas, J.I.G. Ibarguchi, Sequential Development of the Metamorphic Aureole Beneath the Ronda Peridotites and its Bearing on the Tectonic Evolution of the Betic Cordillera, Tectonophysics 279 (1997) 227-252.

[50] S.P. Turner, J.P. Platt, R.M.M. George, S.P. Kelley, D.G. Pearson, G.M. Nowell, Magmatism Associated with Orogenic Collapse of the Betic-Alboran Domain, SE Spain, J. Petrol. 40 (1999) 1011-1036

[51] B. Wernicke, Cenozoic extensional tectonics of the US Cordillera, in: B.C. Burchfiel, P.W. Lipman, M.L. Zoback (Eds.), The Cordilleran Orogen: Conterminous US G-3, Geol. Soc. Am., The Geology of North America, Boulder, CO, 1992, pp. 553-581.

[52] H.P. Zeck, M.J. Whitehouse, Hercynian, Pan-African, Proterozoic and Archean ion-microprobe zircon ages for a Betic-Rif core complex, Alpine Belt, W. Mediterranean - Consequences for its $P-T-t$ Path, Contrib. Mineral. Petrol. 134 (1999) 134 149. 